\title{
Relevant drivers of farmers' decision behavior regarding their adaptation to climate change: a case study of two regions in Côte d'Ivoire
}

\author{
Hermann Comoé • Michael Siegrist
}

Received: 20 March 2013 / Accepted: 21 June 2013 / Published online: 17 July 2013

(C) Springer Science+Business Media Dordrecht 2013

\begin{abstract}
In addition to many other stressors, climate change has emerged as one of the major threats for smallholder farmers from Toumodi in the center and Korhogo in the north of Côte d'Ivoire. This study examined farmers' adaptation behavior with respect to subjective, socio-demographic, institutional, and physical variables. Focus group discussions with 205 farmers and large-scale surveys involving 800 farmers' households were conducted in both study areas for data collection. The data were analyzed using a categorical principal component analysis (CATPCA), reliability analyses, and binary logistic regression models to determine relevant influences on farmers' adaptation behavior. The results revealed that $77 \%$ of farmers perceived high increases in temperature and $75 \%$ perceived strong decreases in rainfall over the last 10 years. Farmers in Toumodi perceived more climate change than their colleagues in Korhogo. In addition, farmers from Korhogo perceived more new pests $(81 \%)$ and new weeds $(87 \%)$, while those from Toumodi agreed that there were strong changes in flowering and fruiting times (54\%). Furthermore, two main adaptation groups were identified: changes in the sowing management and the technical itinerary. The levels of implemented strategies differed significantly across regions. Factors such as the perceived occurrence of new pests and insects and support from national and international organizations were relevant to farmers' decision to adapt to climate change. Moreover, the agro-ecological specificities, the types of food crops, and the owners of livestock had also an influence on farmers' adaptation choices. The appropriate policy response should henceforth integrate these factors to support efficient adaptation processes in response to climate change in Côte d'Ivoire.
\end{abstract}

Keywords Adaptation behavior - Climate change - Smallholders - Categorical principal component analysis · Logistic regression · Côte d'Ivoire

\footnotetext{
H. Comoé $(\bowtie)$

Institute for Environmental Decisions (IED), Agricultural Economics (AGECON), ETH Zürich, Sonneggstrasse 33, 8092 Zürich, Switzerland

e-mail: hecomoe@ethz.ch

M. Siegrist

Institute for Environmental Decisions (IED), Consumer Behavior, ETH Zürich, Universitätstrasse 22, 8092 Zürich, Switzerland

e-mail: msiegrist@ethz.ch
} 


\section{Introduction}

Climate change is emerging as one of the main threats to sustainable food security in developing countries. In particular, climate change is expected to affect agricultural production due to increasing temperatures, changing precipitation patterns, and more frequent extreme weather events. It is estimated that the mean global temperature will rise by $1.8-$ $4.0^{\circ} \mathrm{C}$ by the end of the twenty-first century (Izaurralde 2009), which will reduce the yields from rain-fed agriculture in some regions by up to $50 \%$ by 2020 (IPCC 2007). This is particularly relevant for Africa because livelihoods are based mainly on climate-dependent resources and environmental factors. The effects of climate change in Africa will thus be disproportionate and severe (Asfaw and Jones 2010).

Located between latitudes $4^{\circ} 30^{\prime}$ and $10^{\circ} 30^{\prime} \mathrm{N}$ and longitudes $2^{\circ} 30^{\prime}$ and $8^{\circ} 30^{\prime} \mathrm{W}$, Côte d'Ivoire, a western African country where agriculture drives a market-based economy, is experiencing the adverse effects of climate change. Changes in climatic conditions that have already been observed in Côte d'Ivoire (MEDD 2011) are especially characterized by variations in the seasons' start and end dates, leading to a disturbance in the agricultural calendar (Ochou 2011; Goroza 2012). Moreover, an increase in the frequency of storms and heavy rainfalls has been observed (Ochou 2011); several sources (Brou and Chaléard 2007; Kanohin et al. 2009; Goula et al. 2010) have revealed a general reduction in the annual quantity of rainfall since the seventies and a shortening of the rain seasons. Indeed, annual rainfall decreased by an average of $0.5 \%$ per year between 1965 and 1980 and by $4.6 \%$ per year in the 1980s (MET 1994; Birgit and Bruzon 2006). Furthermore, models of the change in the average daily maximum temperature for the warmest month of the year showed an increase in temperature up to $2.5^{\circ} \mathrm{C}$ by 2050 (Ahossane et al. 2013). Decreasing levels of rainfall affect both the bimodal rainfall pattern of the southern region and the unimodal rainfall pattern of the northern region of Côte d'Ivoire. Rural areas are the most affected by climate change because agricultural activity is their main source of income (MEDD 2011). For instance, a yield loss of 5-25\% of baseline for rice in the central and northeast regions of the country has been predicted by 2050 (Ahossane et al. 2013). This is of special relevance because most farmers engage in agricultural practices that depend on the amount and the seasonal distribution of rainfall.

Changes in climatic conditions are exacerbated by the development of other severe environmental problems such as large-scale deforestation. From 12 million hectares of forest in 1960 , only 2.802 million hectares remained in 2007, which represents a loss of more than $75 \%$ in less than half a century (MEDD 2011).

One of the ways communities can adjust to climate change is through adaptation (IPCC 2001). Common adaptation methods in agriculture include the use of new crop varieties and livestock species that are better suited to drier conditions, irrigation, crop diversification, the adoption of mixed crop and livestock farming systems, and the changing of planting dates (Deressa et al. 2009; Di Falco et al. 2011). The main aim of almost all of these practices is to ensure that crops' critical growth stages do not overlap with dry periods or mid-season droughts. Farmers' decision to adjust their farming practices is influenced by a number of factors in addition to the climate stimulus (Silvestri et al. 2012). Past studies (Nielsen and Reenberg 2010; Deressa et al. 2009; Sietz et al. 2011; Esham and Garforth 2012) have pointed out a number of factors, including social, economic, and cultural influences, as well as government policies, the institutional environment, farmers' access to information, and cognitive domains. In addition, farm characteristics or infrastructures, access to credit and community perceptions determine farmers' adaptation behavior (Piya et al. 2013; Hisali et al. 2011; Gbetibouo et al. 2010). Indeed, multinomial logit (MNL) models have been often 
used to analyze influencing factors of farmers' adaptation choice (Gbetibouo 2009; Deressa et al. 2009; Hisali et al. 2011); however, the major limitation of MNL models is their assumption that practices are mutually exclusive, which is not true in reality because a single household can simultaneously adopt more than one strategy (Piya et al. 2013).

Furthermore, farmers' behavior is shaped more by their perceptions of climate change and climate risk than by the actual climate patterns (Adger et al. 2009; Mertz et al. 2009). In order to develop appropriate strategies and institutional responses, it is necessary to have a clear understanding of farmers' perception of climate change, the actual adaptations at the farm level, and what factors drive and constrain farmers' decision to adapt (Esham and Garforth 2012). Because adaptation is often conceptualized as a site-specific phenomenon, many authors call for more local-level analyses to gain a better understanding of the fundamental processes underlying adaptation and to better target adaptation policies by national and local governments, non-governmental organizations (NGOs), and bi-lateral donors (Smit and Wandel 2006). Such research in Côte d'Ivoire is very scarce, and understanding the determinants of a household decision to adopt a particular practice among the available choices may provide insights into the factors that enable or constrain adaptation to climate change.

Based on this background, the goal of this study is to investigate farm-level adaptation to climate change through farmers in two regions of Côte d'Ivoire. Specifically, the objectives of the study are: (i) assess farmers' perceptions of climate change; (ii) identify the main current adaptation strategies; and (iii) determine relevant drivers of adaptation. To this end, focus group discussions and large-scale surveys were conducted in two regions of Côte d'Ivoire. Based on the derived data, we were able to analyze farmers' adaptation behavior with respect to subjective, socio-demographic, institutional, and physical variables.

\section{Methods}

\subsection{Study areas}

Côte d'Ivoire is divided into two main agro-climatic regions following the pattern of temperature and rainfalls. The forest zone of the south has a sub-equatorial climate and two rainy seasons. The north is characterized by a tropical climate of the Soudano-Guinean type and has only one rainy season (FAO 2000). The dry season is now longer in the north as well as in the center of the country (Brou et al. 2005; Dje 2008). This reduces the availability of water, especially by decreasing the length of time rainfall is accessible for agriculture and thus compromising the vegetation cycles.

The study was carried out in two departments of Côte d'Ivoire, namely the Toumodi area in the center and the Korhogo area in the northern part of the country. As in most areas of the country, agricultural fields are mainly rain-fed (Birgit and Bruzon 2006; Tié Bi et al. 2010).

Toumodi is a mid-sized city and a department $230 \mathrm{~km}$ north of the capital Abidjan. It has an area of $2,780 \mathrm{~km}^{2}$ (Ouattara 2001) and a population of 147,105 inhabitants in 2009. In 2001, $65 \%$ of the population was rural (CountrySTAT 2012). This region is a producer of yams (Dioscorea spp.) and other important crops such as cocoa (Theobroma cacao) and coffee (Coffea robusta). Since 2001, rubber (Hevea brasiliensis) and palm oil (Elaeis guineensis) have been gaining importance in the forest zone (PAM et al. 2012). Toumodi is located in the Sudano-Guinean area, a transition zone between the forest zone in the south and the savanna in the north. It has a humid tropical climate (Baouléen), with temperatures 
between 14 and $39^{\circ} \mathrm{C}$ (Table 1). It is characterized by four seasons: a long dry season (November-February), a long rainy season (March-June), a short dry season (July-August), and a short rainy season (September-October), and a relative humidity of 60 to $70 \%$ (Birgit and Bruzon 2006). The average annual precipitation in the period from 1980 to 2011 was $1,113 \mathrm{~mm}$. The Toumodi area includes a mosaic of environments, composed of mesophile forest (or semi-deciduous) and Guinean savanna (MEDD 2011).

Korhogo, in the Sudanean zone of the north, is located $600 \mathrm{~km}$ north of Abidjan, near the border of Mali. This region is closer to the desert, and vegetation is scarcer due to a drier climate. Korhogo is 12,500 km² (Ouattara 2001) wide and had 630,725 inhabitants in 2009. In 2001, $80 \%$ of the population was active in agriculture (CountrySTAT 2012). The north region cultivates mostly cotton (Gossypium spp.), as well as cashew trees (Anacardium occidentale) and fruit trees like mango for cash crops and various food crops and livestock (Birgit and Bruzon 2006). The north region is the poorest of the country with a poverty rate of more than $70 \%$. Korhogo is a savanna region with only one rainy season and a relative humidity of 40 to $50 \%$. Rain-fed crops are more dominant (maize (Zea mays), rice (Oryza spp.), and groundnuts (Arachis hypogaea)). About $40 \%$ of farms in the region produce cotton. Perennial crops (mango (Mangifera indica), shea trees (Vitellaria paradoxa)) and livestock are also important sources of income (Birgit and Bruzon 2006). The average annual precipitation from 1971 to 2001 was $1,300 \mathrm{~mm}$. The area is characterized by the intermittent presence of a cool and dry wind called harmattan, which occurs between December and February (UFR-STRM 2009).

Therefore, the diversity of the vegetation and socio-demographic and climatic characteristics in the study areas will provide a more holistic view of climate change issues.

\subsection{Data collection}

This study employed both qualitative and quantitative methodologies in the Toumodi and Korhogo regions of Côte d'Ivoire (see Fig. 1); between June and August 2011, qualitative data were collected through 16 focus groups to gain the first insights into processes shaping farmers' adaptation behavior. Focus groups are used as a method of collecting data through group interactions on a topic determined by the researcher (Morgan 1997). Sessions of about 1 hour, with 10 to 12 farmers, involved a total of 205 participants selected based on the

Table 1 Socio-economic and biophysical characteristics of the study areas in Cote d'Ivorie

\begin{tabular}{lll}
\hline & Toumodi (Center) & Korhogo (North) \\
\hline Location & $6^{\circ} 32^{\prime} \mathrm{N}$ and $5^{\circ} 1^{\prime} \mathrm{W}$ & $9^{\circ} 53^{\prime} \mathrm{N}$ and $6^{\circ} 49^{\prime} \mathrm{W}$ \\
Altitude (meters above sea level) & 152 & 200 \\
Vegetation & Transition forest-savanna & Savanna \\
Climate & Tropical humid (baouléen) & Tropical (soudano-guinéen) \\
Humidity (\%) & $60-70$ & $40-50$ \\
Average annual precipitation $(\mathrm{mm} /$ year) & 1,113 (years 1980-2011) & 1,300 (years 1971-2001) \\
Range of average temperature $\left({ }^{\circ} \mathrm{C}\right)$ & $14-39$ & $10-42$ \\
Rainfall regime & Bimodal & Unimodal \\
Dry season & Nov-Feb \& Jul-Aug & Nov-April \\
Rainy season & March-June \& Sept-Oct & May-Oct \\
\hline
\end{tabular}

Cissé et al. 2011; Birgit and Bruzon 2006; MEDD 2011; MPARH 2003 


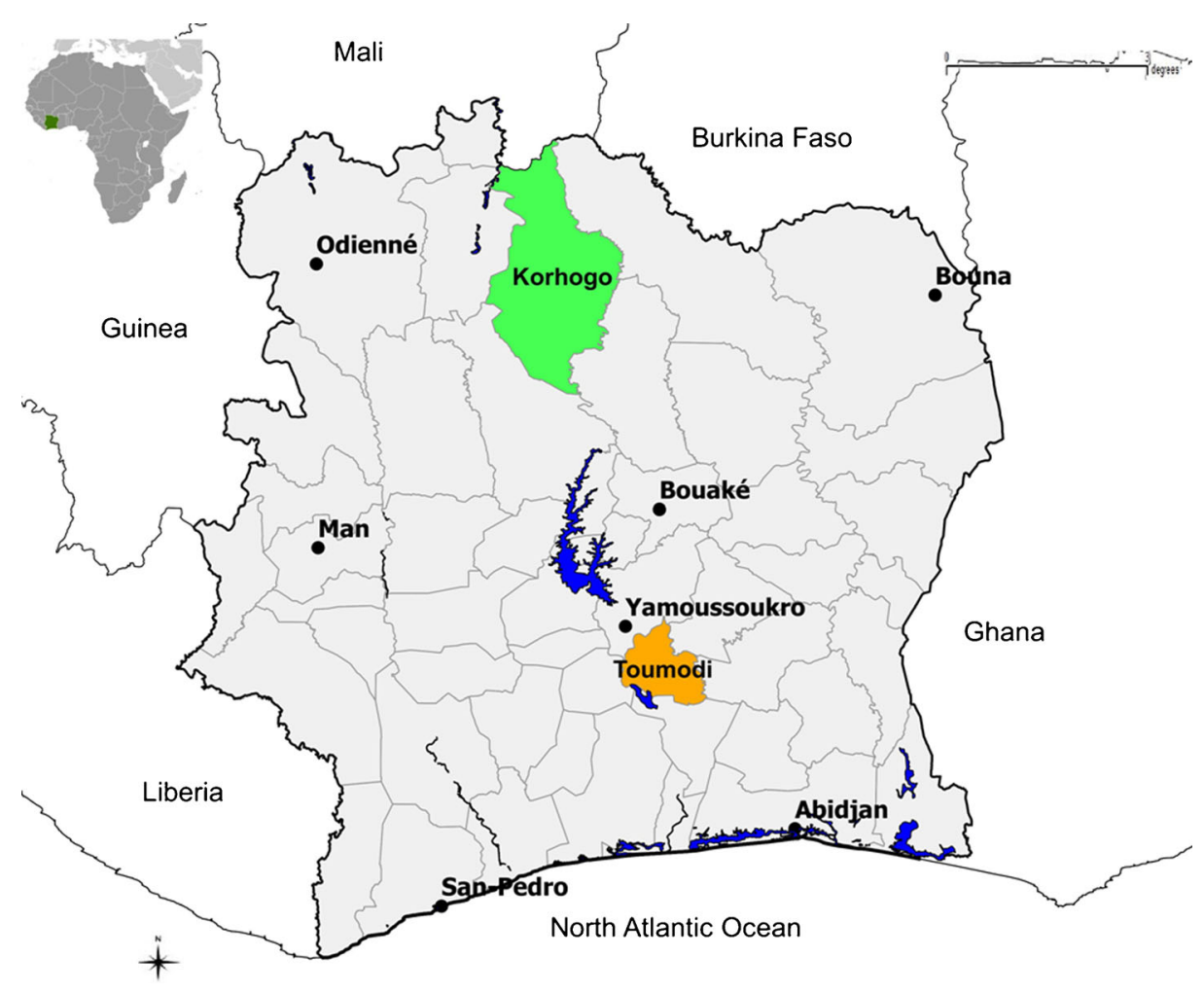

Fig. 1 Map of the study areas in Cote d'Ivorie

geographical location of the villages, the types of farming activities, and the age of farmers. The discussions were recorded and translated in French. Furthermore, the socio-cultural differences between the two areas were considered. In Korhogo (the Muslim and conservative part of the country), women and men were separately interviewed, which was not the case in Toumodi. Krueger's (1994) method has been applied by continuing with the focus groups until a clear pattern emerged and subsequent groups produced only repetitious information (theoretical saturation). Finally, nine villages in Toumodi and four in Korhogo were investigated.

Data were analyzed using NVivo (www.qsrinternational.com/products_nvivo.aspx) software for qualitative data analysis, which helped us to understand farmers' decision-making process regarding the management of their farms, their perceptions of climate change, and how they deal with climatic risk.

The results of the focus groups were used to elaborate upon a questionnaire for the survey conducted between February and April 2012. The sample consisted of 800 farmers' households, with 400 selected from each study area using a quota sampling technique, as the last general census of farmers was conducted in 1998 (Gschwend 2005; Moser 1952). Quota sampling is particularly useful when we are unable to obtain a probability sample but are still trying to create a sample that is as representative as possible of the population being studied. Thereby, we based our sampling on the statistical data from the most important extension service, the national rural development support agency (ANADER), reflecting information on the farming populations in both regions. Indeed, quotas were computed based on 4,049 farmers from 12 villages in Toumodi and 3,700 involving eight villages in Korhogo. 
Significant criteria considered in the sampling process were gender, geographic location, and farming type (perennial, annual crop, vegetable, and livestock). The details of the quota sampling plan for the survey are presented in Table 2. Furthermore, with quota sampling methods, some biases could be introduced during the process of selecting farmers by not complying with the selection criteria. For the purpose of uniformity, the survey was conducted with the support of field assistants who were thoroughly trained in survey interviewing procedures. Moreover, interviews were conducted in compliance with quotas to improve the representation of particular strata (groups) within the population, as well as ensuring that these strata are not over-

Table 2 Sampling plan for the survey of farmers

\begin{tabular}{|c|c|c|c|c|c|c|}
\hline & \multicolumn{2}{|c|}{ Geographic segment } & \multicolumn{2}{|l|}{ Type of farming } & \multicolumn{2}{|l|}{ Gender } \\
\hline & Village & Number & Activity & Number & Woman & Man \\
\hline \multirow[t]{16}{*}{ Toumodi $(N=400)$} & Gofia & 14 & Periannual crop & 31 & 20 & 80 \\
\hline & N'gbedjo & 86 & Annual crop & 33 & & \\
\hline & & & Vegetable & 33 & & \\
\hline & & & Livestock & 3 & & \\
\hline & Kadjokro & 36 & Periannual crop & 31 & 20 & 80 \\
\hline & Anikro & 26 & Annual crop & 33 & & \\
\hline & Zahakro & 38 & Vegetable & 33 & & \\
\hline & & & Livestock & 3 & & \\
\hline & Djékanou & 27 & Periannual crop & 31 & 20 & 80 \\
\hline & Laliekro & 25 & Annual crop & 33 & & \\
\hline & N'dakouassikro & 34 & Vegetable & 33 & & \\
\hline & Yao N'drikro & 14 & Livestock & 3 & & \\
\hline & Gbonti & 26 & Periannual crop & 31 & 20 & 80 \\
\hline & Kimoukro & 50 & Annual crop & 33 & & \\
\hline & Ahouekro & 23 & Vegetable & 33 & & \\
\hline & & & Livestock & 3 & & \\
\hline \multirow[t]{16}{*}{ Korhogo $(N=400)$} & Dikodougou & 70 & Periannual crop & 29 & 30 & 70 \\
\hline & Karakpo & 30 & Annual crop & 38 & & \\
\hline & & & Vegetable & 17 & & \\
\hline & & & Livestock & 16 & & \\
\hline & Koni & 70 & Periannual crop & 29 & 30 & 70 \\
\hline & Famangaha & 30 & Annual crop & 38 & & \\
\hline & & & Vegetable & 17 & & \\
\hline & & & Livestock & 16 & & \\
\hline & Dagba & 60 & Periannual crop & 29 & 30 & 70 \\
\hline & Sakouélé & 40 & Annual crop & 38 & & \\
\hline & & & Vegetable & 17 & & \\
\hline & & & Livestock & 16 & & \\
\hline & Kouniguekaha & 50 & Periannual crop & 29 & 30 & 70 \\
\hline & Pokaha & 50 & Annual crop & 38 & & \\
\hline & & & Vegetable & 17 & & \\
\hline & & & Livestock & 16 & & \\
\hline
\end{tabular}

Quotas were computed based on the characteristics of farmers from ANADER 
represented. Thus, attention to the geographical distribution of farmers was pointed out. Investigators have been trained to follow the instructions regarding compliance with the quotas and the geographical distribution of farmers' households. Moreover, instructions such as avoiding interviews with farmers of one type of crop farming activities and changing the period of interviews throughout the day have been considered. Finally, participants' average age was 45 years, and the average household size was 10 people. The level of education in Korhogo was much lower than that in Toumodi, while the average number of years of experience in crop farming and livestock production was 22.32 years and 10.20 years, respectively.

The survey was intended to collect information on farmers' perceptions of climate characteristics during the last decade and the effects of climate change on farming and the natural environment. In this section, participants were asked about their perceptions of changes in the temperature, the amount of rainfall, and dry spell and rainfall frequencies. Moreover, we collected information on the possible causes of climate change and on adaptation strategies that have already been implemented. Farmers' adaptations, their intention to adapt in the future, and the social pressure to adapt were assessed through questions about their expectations regarding implementing certain adaptation procedures and the ways in which family members could impede or motivate their decision to adapt. General household characteristics (e.g., gender of household head, education, age), and the farm type were also recorded in this survey. Information relating to each household's access to support from key agricultural institutions such as extension services, governmental and Non-governmental Organization (NGOs), and finally, the type and frequency of advice from extension services were also integrated.

\subsection{Data analysis}

First, CATPCA and reliability analyses were used. Then, binary logistic regression models were applied to determine the relevant factors influencing farmers' adaptation behavior.

\subsubsection{Categorical principal component analysis and reliability analysis}

In this study, the process used to identify the most important factors of farmers' adaptation behavior consisted of two steps. First, we conducted a CATPCA to reduce the dimensions of the dataset to a smaller set of uncorrelated components and to determine the underlying latent dimensions within groups of factors. Thereby, four different subsets of variables related to subjective, socio-demographic, agronomic, and institutional factors were separately reduced.

The CATPCA also helped us to avoid problems of multicollinearity in the subsequent regression analyses. Furthermore, the variables were assigned to components based on their largest loading, and then Cronbach's alpha coefficient was calculated to determine the scale reliability of the dimensions. The coding of variables used for the CATPCA and the descriptive statistics are presented in Tables 3 and 4. The analyses were carried out using statistical package for social sciences (SPSS) 17.0 for Windows (Statistical Package for Social Sciences, SPSS Inc.).

\subsubsection{Logistic regression}

The factors derived from the CATPCA were employed to explain farmers' behavior regarding their adaptation to climate change in a binary choice model. Factors were retained for the regressions if their eigenvalues were $>1$ and the Cronbach's alpha was greater than 0.5 . Farmers' decision to adapt was modeled using a binary logistic regression (following Field 2009). Table 5 shows the groups of variables and their associated hypotheses with regard to their influence on adaptation to climate change based on the literature review. 
Table 3 Descriptive variable coding of farmer survey

Variables Description

Study area

Root, tuber or starchy farmer

Cash crop farmer

Cereal farmer

Experience in crop farming (years)

Age of head of household (years)

Size of household

Bovine ownership / Small ruminant $\&$ porcine ownership

Frequency of dry spells / Frequency of rainfall

Length of rainy seasons / Length of dry spells

Effect of climate change on cereals / Effect of climate change on roots \& tubers

Disturbance of the farming calendar

Yield variations

Perceived new insect pests / Perceived new weed species

Contact with development projects / Ministry of Agriculture / NGOs / International organization / Swiss Centre of Research / National Centre of Research / ANADER

Climate information from television

Membership in a farming cooperative
1=Toumodi, 2=Korhogo

$1=$ the household head is a producer of root, tuber or starchy, $0=$ otherwise

$1=$ the household head is a producer of cash crop, $0=$ otherwise

$1=$ if the household head is a producer of cereal, $0=$ otherwise

$1=$ if the experience $\leq 10,2=[11 ; 20], 3=[21 ; 30]$, $4=[31 ; 40], 5=[40 ;+[$

$1=$ if the age $<30,2=[31 ; 60], 3=[61 ;+[$

$1=[1 ; 5], 2=[6 ; 10], 3=[11 ; 15], 4=[16 ; 20]$, $5=[21 ;+[$

$1=$ owner, $0=$ otherwise

$1=$ high decrease over the last decade, $2=$ average decrease, $3=$ no change, $4=$ average increase, $5=$ high increase

$1=$ high decrease over the last decade, $2=$ average decrease, $3=$ no change, $4=$ average increase, $5=$ high increase

$1=$ high negative impact, $2=$ average negative impact, $3=$ non-significant, $4=$ average beneficial, $5=$ highly beneficial

1=high significant disturbance, $2=$ average disturbance, $3=$ non-significant disturbance

$1=$ high significant variation, $2=$ average, $3=$ non-significant

$1=$ strongly agree, $2=$ somewhat agree, $3=$ do not know, $4=$ somewhat disagree, $5=$ strongly disagree

$1=$ often, $2=$ rarely, $3=$ never

$1=$ the household head obtained information from television, $0=$ otherwise

$1=$ the household head is a member of a farming organization, $0=$ otherwise

\section{Results and discussion}

\subsection{Farmers' perceptions of and adaptation strategies to climate change}

Farmers' perceptions of climate change were strong in both study areas: $77 \%$ of farmers perceived high increases in temperature, and $75 \%$ perceived strong decreases in rainfall over the last 10 years. Farmers noticed an increase in the frequency and length of dry spells, while they believed the frequency and length of rainfall and rainy seasons were still decreasing. However, $27 \%$ of farmers in Toumodi (52\% in Korhogo) moderated their assertions related 
Table 4 Descriptive statistics of variables selected in farmer survey

\begin{tabular}{|c|c|c|c|c|}
\hline Variables & Mean & $\mathrm{SD}$ & Min & Max \\
\hline Frequency of dry spells & 4.56 & 0.58 & 1 & 5 \\
\hline Length of rainy season & 1.34 & 0.59 & 1 & 5 \\
\hline Frequency of precipitation & 1.37 & 0.52 & 1 & 4 \\
\hline Length of dry spells & 4.70 & 0.53 & 1 & 5 \\
\hline Perceived new insect pests & 1.72 & 1.12 & 1 & 5 \\
\hline Perceived new weed species & 1.68 & 1.15 & 1 & 5 \\
\hline Effect of climate change on roots \& tubers & 1.40 & 0.57 & 1 & 4 \\
\hline Effect of climate change on cereals & 1.31 & 0.57 & 1 & 4 \\
\hline Disturbance of the farming calendar & 1.24 & 0.50 & 1 & 4 \\
\hline Yield variation & 1.42 & 0.58 & 1 & 4 \\
\hline Contact with ANADER & 2.15 & 0.92 & 1 & 3 \\
\hline Contact with Ministry of Agriculture & 2.81 & 0.46 & 1 & 3 \\
\hline Contact with international organization & 2.86 & 0.44 & 1 & 3 \\
\hline Contact with development projects & 2.80 & 0.50 & 1 & 3 \\
\hline Contact with NGOs & 2.67 & 0.67 & 1 & 3 \\
\hline Contact with National Centre of Research & 2.84 & 0.47 & 1 & 3 \\
\hline Contact with Swiss Centre of Research & 2.79 & 0.44 & 1 & 3 \\
\hline Study area & 1.50 & 0.50 & 1 & 2 \\
\hline Root, tuber or starchy crop farmer & 0.63 & 0.48 & 0 & 1 \\
\hline Climate information from television & 0.47 & 0.50 & 0 & 1 \\
\hline Bovine ownership & 0.25 & 0.43 & 0 & 1 \\
\hline Membership of a farming cooperative & 0.40 & 0.49 & 0 & 1 \\
\hline Small ruminant and porcine ownership & 0.42 & 0.49 & 0 & 1 \\
\hline Cereal farmer & 0.76 & 0.43 & 0 & 1 \\
\hline Experience in crop farming (category) & 2.32 & 1.08 & 1 & 5 \\
\hline Age (category) & 2.02 & 0.50 & 1 & 3 \\
\hline Size of household (category) & 2.40 & 1.04 & 1 & 5 \\
\hline Cash crop farmer & 0.83 & 0.38 & 0 & 1 \\
\hline
\end{tabular}

to the intensity of climate change through a perceived average increase in dry spells, and $23 \%$ (46\% in Korhogo) perceived an average decrease in rainfall (see Fig. 2). The chisquare tests applied to the study areas revealed significant differences between farmers in Korhogo and Toumodi with respect to their perception of changes in climatic conditions, except for perceived changes in the amount of rainfall. More specifically, farmers from Toumodi seemed to perceive more climate changes than their colleagues in Korhogo. This could be explained by the fact that farmers in Korhogo have to deal with climatic threats such as water scarcity more often, which makes it more difficult for them to recognize changes. In contrast, farmers in Toumodi perceived any change in climate as a serious threat. This result also confirmed the findings from the focus groups, which showed the level of farmers' perceptions of climate change was higher in Toumodi than in Korhogo (Comoé et al. 2012).

In addition to their perceptions of changes in rainfall and temperature, we asked farmers to give their views on statements about changes in their environment. In general, we found that farmers in both regions had a strong perception of changes in their local environment. 
Table 5 Variables and associated hypothesis in farmer survey

\begin{tabular}{|c|c|c|}
\hline \multicolumn{2}{|l|}{ Variables } & \multirow{2}{*}{$\begin{array}{l}\text { Hypotheses } \\
\text { The agro-ecological zone captures heterogeneity in ecological } \\
\text { conditions (Tambo and Tahirou 2012; Silvestri et al. 2012). }\end{array}$} \\
\hline Physical & Agro-ecological zone & \\
\hline \multirow[t]{5}{*}{$\begin{array}{l}\text { Socio- demographic } \\
\text { and agronomic }\end{array}$} & $\begin{array}{l}\text { Experience in } \\
\text { crop farming }\end{array}$ & $\begin{array}{l}\text { The experience of the head of the household is expected to } \\
\text { influence the decision to adapt (Igoden et al. 1990). }\end{array}$ \\
\hline & Household size & $\begin{array}{l}\text { The influence of the household size on adaptation is assumed } \\
\text { to be positive (Yirga 2007) or negative (Croppenstedt } \\
\text { et al. 2003; Nhemachena and Hassan 2007). }\end{array}$ \\
\hline & Livestock ownership & $\begin{array}{l}\text { Livestock could play a very important role by serving as } \\
\text { a store of value and by providing traction and manure } \\
\text { required for maintaining soil fertility (Yirga 2007). } \\
\text { It is an indicator of wealth (Solano et al. 2000), so } \\
\text { higher-income farmers may be less averse to taking risks. }\end{array}$ \\
\hline & Type of farm & $\begin{array}{l}\text { It is assumed farm type influences farmers' behavior. } \\
\text { Maddison (2007) asserted that subsistence farmers } \\
\text { are more capable of perceiving changes in climate, } \\
\text { while Gbetibouo (2009) showed the opposite. }\end{array}$ \\
\hline & Social network & $\begin{array}{l}\text { Members of farmer associations may have better access to } \\
\text { information, credit and inputs and are, therefore, more } \\
\text { likely to adopt technology than non-members } \\
\text { (Tambo and Tahirou 2012). }\end{array}$ \\
\hline \multirow[t]{2}{*}{ Subjective } & $\begin{array}{l}\text { Perception of } \\
\text { climate change }\end{array}$ & $\begin{array}{l}\text { Perception of climate change is assumed to be a } \\
\text { necessary prerequisite for adaptation } \\
\text { (Hansen et al. 2004; Thomas et al. 2007). }\end{array}$ \\
\hline & $\begin{array}{l}\text { Perception of climate } \\
\text { change impacts }\end{array}$ & $\begin{array}{l}\text { When farmers perceive climate change and consider it } \\
\text { to affect their livelihood, they are expected to be more } \\
\text { likely to take adaptation measures (Esham and } \\
\text { Garforth 2012; Adger et al. 2009). }\end{array}$ \\
\hline \multirow[t]{2}{*}{ Institutional } & $\begin{array}{l}\text { Access to extension } \\
\text { services }\end{array}$ & $\begin{array}{l}\text { Access to extension services and information are expected } \\
\text { to facilitate decision making with regard to adaptation } \\
\text { to climate change (Bryan et al. 2009; Deressa et al. 2009; } \\
\text { Gbetibouo 2009; Maddison 2007; Tambo and Tahirou 2012) }\end{array}$ \\
\hline & $\begin{array}{l}\text { Climate information } \\
\text { sources }\end{array}$ & $\begin{array}{l}\text { Lack of information is assumed to be one of the major } \\
\text { reasons for not undertaking any adaptation strategy } \\
\text { (Di Falco et al. 2011). It is expected that farmers who } \\
\text { have heard or read about climate change and its negative } \\
\text { consequences are likely to take up adaptation measures } \\
\text { (Tambo and Tahirou 2012). }\end{array}$ \\
\hline
\end{tabular}

For instance, $90 \%$ of farmers in Toumodi and $85 \%$ in Korhogo strongly agreed that rainfall was unpredictable. It is worth noticing significant differences in the views of farmers from both study areas concerning the emergence of new weed species and new insect pests in agriculture and the changes in flowering and fruiting times. Farmers from Korhogo perceived more new pests $(81 \%)$ and new weeds $(87 \%)$, while those from Toumodi agreed that there were significant changes in flowering and fruiting times $(54 \%)$.

\subsection{Adaptation strategies to climate change}

Focus groups were used to identify specific adaptation strategies to climate change, and the survey confirmed these strategies on a large scale. Figure 3 shows all 


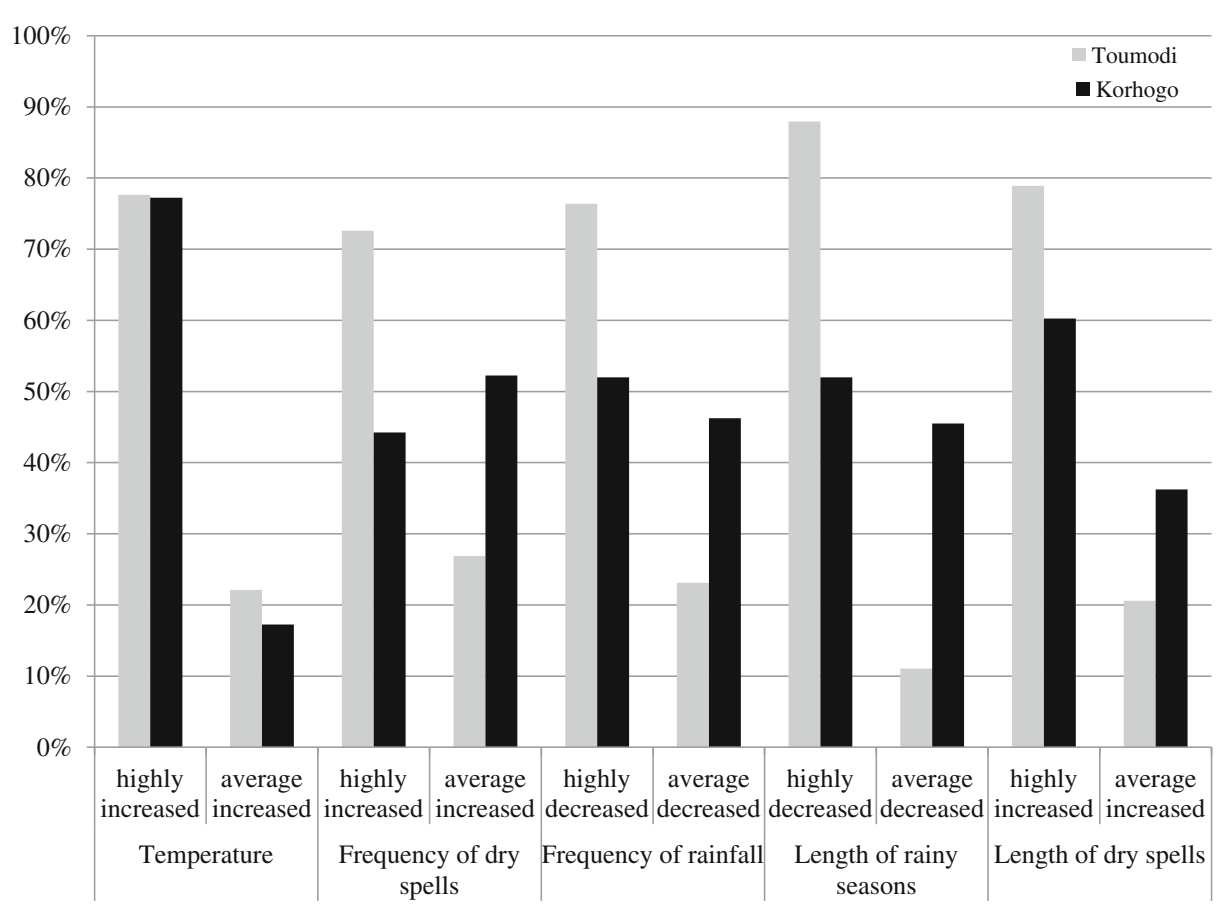

Fig. 2 Farmers' perception of long-term of temperature, rainfall, and dry spells in Toumodi and Korhogo (\% of respondents)

identified strategies in crop farming and livestock production as well as non-farming strategies.

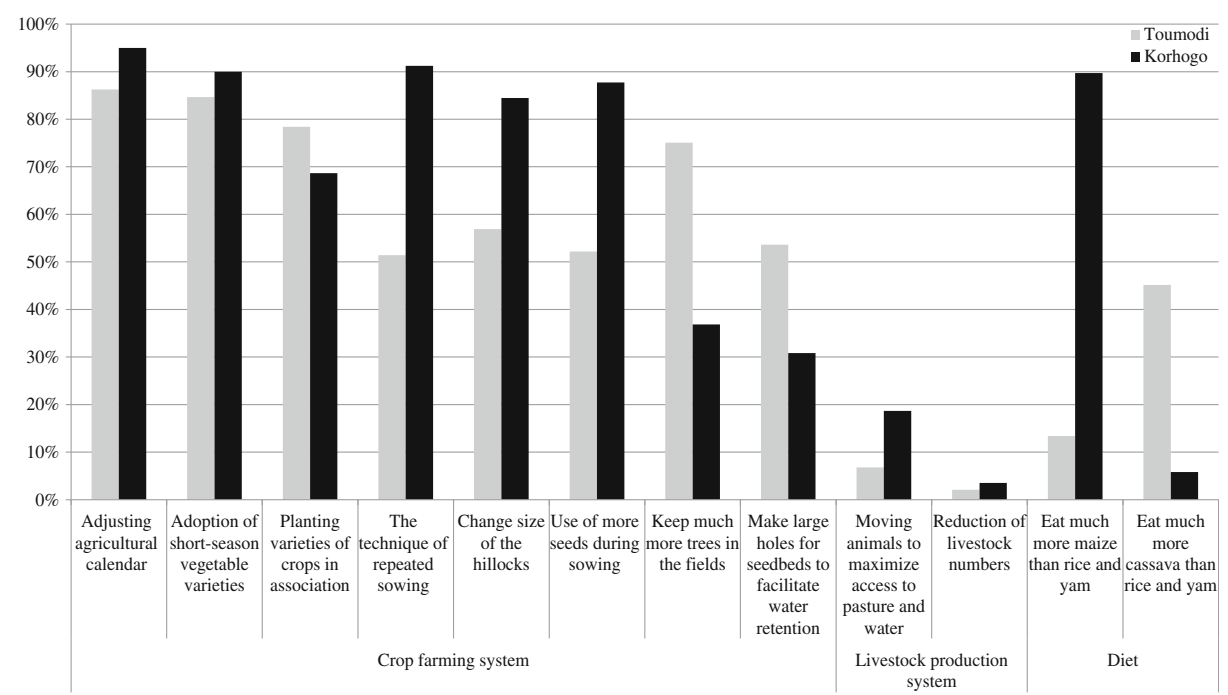

Fig. 3 Farmer strategies for coping with climate change in Toumodi and Korhogo 


\subsubsection{Crop farming systems}

Eight strategies were identified in the crop farming system, and these were divided into two main groups. The first was adaptation through sowing management, which included "the technique of repeating sowing," "the use of more seeds during sowing," and "making large holes for seedbeds to facilitate water retention." The second adaptation strategy was done through changing the technical itinerary, which is defined as logical and orderly techniques implemented on a farm to help it achieve its production goal (Sebillotte 1974). This definition takes into account the coherence and interactions of the techniques and the explicit reference to a production target. The levels of implemented strategies differed significantly across regions, except for the adoption of vegetables with a short growing season. The latter finding demonstrated that farmers in both study areas were open to adopting new varieties that are more suitable to the new climatic conditions. Moreover, "adjusting the agricultural calendar," "the technique of repeating sowing," "the use of more seeds during sowing," and "changes in the size of hillocks" were implemented more in Korhogo, while "planting varieties of crops in association," "making large holes for seedbeds," and "keeping much more trees on the field" were more dominant in Toumodi.

\subsubsection{Livestock production system and diet}

Regarding the adaptation of livestock systems, two main strategies were mentioned: the reduction of animals to ensure there is sufficient grass available during dry spells, and better health monitoring. The second strategy was implemented to increase animal mobility to facilitate access to pasture. Of the two study areas, Korhogo was the first where farmers implemented both strategies, with a significant difference in farmers from Toumodi regarding the strategy of "moving animals to maximize access to pasture and water." The north is a pastoral area compared to the center; therefore, farmers in Korhogo have developed the capacity to deal with environmental constraints caused by climate changes over the years. Concerning the modification of food habits, one could assert that although farmers are still linked to their staple foods of rice and yams, they showed more interest in consuming cassava in Toumodi and maize in Korhogo. Indeed, their staple foods are becoming vulnerable to the new climatic conditions; therefore, they need to adapt their diet with crops that are more resistant to dry spells, such as cassava.

\subsection{Results of CATPCA and reliability analysis}

\subsubsection{Variations in farmers' perceptions of climate change}

Perceived changes in rainfall patterns (C 1) and the perceived occurrence of new pests and weeds (C 2), the two components illustrated in Table 6, show a $64 \%$ total variance of data. The first component represents the variables related to changes in length and frequency of rainfall, and the second component includes the occurrence of pests and weeds. The variable related to changes in dry spells was positively loaded for C 2, while those related to rainfall had a negative loading; as coded (high decrease to high increase), this revealed a perception that there has been an increase in the frequency and length of dry spells and a decrease in the length of rainy seasons and the frequency of rainfall. 
Table 6 Results of CATPCA of variables related to climate change perception and effects, and extension support

\begin{tabular}{|c|c|c|}
\hline Components & $\begin{array}{l}\text { Variables related to climate } \\
\text { change perception }(N=799)\end{array}$ & $\begin{array}{l}\text { Component } \\
\text { loadings }\end{array}$ \\
\hline \multirow{4}{*}{$\begin{array}{l}\text { Perceived changes in rainfall } \\
\text { patterns (C 1) }(\alpha=0.62)\end{array}$} & Frequency of dry spells & 0.75 \\
\hline & Length of rainy seasons & -0.75 \\
\hline & Frequency of rainfall & -0.75 \\
\hline & Length of dry spells & 0.62 \\
\hline \multirow{3}{*}{$\begin{array}{l}\text { Perceived occurrence of new } \\
\text { pests and weeds (C 2) }(\alpha=0.51)\end{array}$} & New insect pests in agriculture & 0.88 \\
\hline & New weeds species seen & 0.87 \\
\hline & \multicolumn{2}{|c|}{ Variables of perceived climate change's effects $(N=783)$} \\
\hline \multirow{4}{*}{$\begin{array}{l}\text { Perceived effects of changes in } \\
\text { production and farming } \\
\text { calendar (C 3) }(\alpha=0.68)\end{array}$} & Effect of climate change on roots \& tubers & 0.86 \\
\hline & Effect of climate change on cereals & 0.79 \\
\hline & Disturbance of the farming calendar & 0.70 \\
\hline & Variables related to extension support $(N=795)$ & \\
\hline \multirow{7}{*}{$\begin{array}{l}\text { Received support from national } \\
\text { and international organizations } \\
\text { (C 4) }(\alpha=0.80)\end{array}$} & Contact with development projects & 0.76 \\
\hline & Contact with NGOs ${ }^{\mathrm{a}}$ & 0.71 \\
\hline & Contact with National Centre of Research & 0.69 \\
\hline & Contact with Ministry of Agriculture & 0.68 \\
\hline & Contact with Swiss Centre of Research & 0.68 \\
\hline & Contact with international organization & 0.66 \\
\hline & Contact with ANADER ${ }^{\mathrm{b}}$ & 0.55 \\
\hline
\end{tabular}

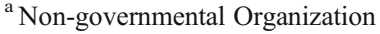

${ }^{\mathrm{b}}$ The national rural development support agency
}

\subsubsection{Variables related to perceived effects of climate change}

Regarding how farmers perceived the effects of climate change on their farming activities, the following variables, "the effect of climate change on roots \& tubers," "the effect of climate change on cereals," and "disturbances in the farming calendar" were identified and loaded on one component. The results of the CATPCA and reliability analyses are presented in Table 6 . The component C 3 was strongly correlated with the perceived effects of climate change on food crop productivity and the disturbance of the farming calendar.

\subsubsection{Variables related to extension support}

The CATPCA and the reliability analyses were applied to variables related to extension support, and the results are presented in Table 6 . One component showed a $45 \%$ variance in the dataset. The variables were all positively loaded on component $\mathrm{C} 4$, "received support from national and international organizations."

\subsubsection{Variables related to farmers and physical characteristics}

The variables loaded on two components showed a $47 \%$ variance in the dataset (Table 7). The two components we interpreted were agro-ecological zone, food crops, and livestock (C 5) and characteristics of the head of the household (C 6). The negative loading in the case of the 
Table 7 Results of CATPCA of variables related to farmers and physical characteristics

\begin{tabular}{|c|c|c|c|}
\hline \multirow[b]{2}{*}{ Variables } & \multicolumn{3}{|l|}{ Rotated component loadings } \\
\hline & $\begin{array}{l}\text { Agro-ecological zone, food } \\
\text { crops and livestock (C 5) }\end{array}$ & $\begin{array}{l}\text { Household head } \\
\text { characteristics (C 6) }\end{array}$ & Total \\
\hline Study area & 0.90 & -0.08 & \\
\hline Root, tuber, or starchy food farmer & -0.76 & 0.21 & \\
\hline Climate information from television & -0.71 & 0.12 & \\
\hline Bovine (Bos taurus indicus) ownership & 0.69 & 0.25 & \\
\hline Member of a farming cooperative & 0.61 & 0.10 & \\
\hline Small ruminant and porcine ownership & 0.52 & 0.22 & \\
\hline Cereal farmer & 0.52 & 0.02 & \\
\hline Experience in crop farming & 0.05 & 0.76 & \\
\hline Age & -0.13 & 0.68 & \\
\hline Household size & 0.08 & 0.68 & \\
\hline Cash crop farmer & -0.11 & 0.40 & \\
\hline Eigenvalues & 3.30 & 1.85 & 5.15 \\
\hline$\%$ of variance & 30.05 & 16.79 & 46.84 \\
\hline Cronbach's alpha & 0.77 & 0.50 & 0.89 \\
\hline
\end{tabular}

Entries in bold indicate the dimension onto which each item was loaded. Number of observation $(N)=756$

variables "root, tuber, and starchy food farmer" and "climate information from television" indicated that the farms in the component $\mathrm{C} 5$ were less oriented to the production of root, tuber, and starchy crops, and farmers did not acquire climate information from television. In addition to cereal production, farmers owned livestock, which was an indicator of wealth.

\subsubsection{Factors influencing farmers' adaptation behaviors to climate change}

Table 8 provides the estimated results for the logistic models that were used to identify factors affecting the probability of farmers' decision to adapt to climate change through changes in sowing management. It also shows the odds ratios that represent the estimated changes in the odds of the adaptation strategy adopted that is caused by a one unit increase in the respective explanatory variable while holding all other variables fixed at their mean values. The overall fit of the logit-specifications was good, with Nagelkerke's R-square ranging between 0.27 and 0.38 .

The results indicated three main components affecting the probability of adaptation: "the perceived occurrence of new pests and weeds," "receiving support from national and international organizations," and "agro-ecological zone, food crops, and livestock." Of the three adaptation strategies, only the technique of making large holes for seedbeds was negatively correlated with the perception of changes in rainfall patterns. As such, this technique was adopted when farmers perceived a decrease in the length of the rainy seasons and the frequency of rainfall. Furthermore, perceiving new pests and weeds motivated the adoption of re-sowing and making large holes for seedbeds, while it negatively influenced the use of more seeds. Indeed, farmers asserted that the method of using more seeds was inefficient when there was a problem with pest attacks and invasive weeds. Therefore, the decision to adapt occurred when farmers made the link between climate change and its 
Table 8 Results from the logistic regression of farmers' adaptation to climate change through sowing management

\begin{tabular}{|c|c|c|c|c|c|c|c|c|}
\hline & \multicolumn{2}{|c|}{$\begin{array}{l}\text { Adaptation } \\
\text { through sowing } \\
\text { management }\end{array}$} & \multicolumn{2}{|c|}{$\begin{array}{l}\text { The technique } \\
\text { of repeated } \\
\text { sowing }\end{array}$} & \multicolumn{2}{|c|}{$\begin{array}{l}\text { Use of more } \\
\text { seeds during } \\
\text { sowing }\end{array}$} & \multicolumn{2}{|c|}{$\begin{array}{l}\text { Make large holes for } \\
\text { seedbeds to facilitate } \\
\text { water retention }\end{array}$} \\
\hline & B & $\begin{array}{l}\text { Odds } \\
\text { ratio }\end{array}$ & B & $\begin{array}{l}\text { Odds } \\
\text { ratio }\end{array}$ & B & $\begin{array}{l}\text { Odds } \\
\text { ratio }\end{array}$ & B & $\begin{array}{l}\text { Odds } \\
\text { ratio }\end{array}$ \\
\hline Constant & $2.88^{\mathrm{b}}$ & 17.79 & $1.50^{\mathrm{b}}$ & 4.48 & $1.32^{\mathrm{b}}$ & 3.74 & $-0.42^{\mathrm{b}}$ & 0.66 \\
\hline $\begin{array}{l}\text { Perceived changes in } \\
\text { rainfall patterns }(\mathrm{C} 1)\end{array}$ & -0.10 & 0.91 & 0.01 & 1.01 & -0.13 & 0.88 & $-0.20^{\mathrm{a}}$ & 0.82 \\
\hline $\begin{array}{l}\text { Perceived occurrence of } \\
\text { new pests and weeds (C 2) }\end{array}$ & $0.57^{\mathrm{a}}$ & 1.76 & $-0.39^{\mathrm{b}}$ & 0.68 & $0.91^{\mathrm{b}}$ & 2.48 & $-0.37^{\mathbf{b}}$ & 0.69 \\
\hline $\begin{array}{l}\text { Perceived effects of } \\
\text { changes in production } \\
\text { and farming calendar (C 3) }\end{array}$ & -0.06 & 0.94 & -0.07 & 0.93 & $-0.28^{\mathrm{a}}$ & 0.76 & $0.58^{b}$ & 1.79 \\
\hline $\begin{array}{l}\text { Received support from } \\
\text { national and international } \\
\text { organizations (C 4) }\end{array}$ & $-0.54^{\mathrm{a}}$ & 0.58 & $-0.65^{b}$ & 0.52 & $-0.26^{\mathrm{a}}$ & 0.79 & $-0.96^{\mathbf{b}}$ & 0.38 \\
\hline $\begin{array}{l}\text { Agro-ecological zone, } \\
\text { food crops, and } \\
\text { livestock (C 5) }\end{array}$ & $1.35^{\mathrm{b}}$ & 3.86 & $1.16^{\mathrm{b}}$ & 3.18 & $1.22^{\mathrm{b}}$ & 3.38 & $-0.79^{b}$ & 0.45 \\
\hline $\begin{array}{l}\text { Household head's } \\
\text { characteristics (C 6) }\end{array}$ & 0.01 & 1.01 & -0.10 & 0.90 & 0.07 & 1.07 & -0.04 & 0.96 \\
\hline Number of observations & 726 & & 727 & & 727 & & 726 & \\
\hline Nagelkerke R Square & 0.27 & & 0.36 & & 0.36 & & 0.38 & \\
\hline
\end{tabular}

${ }^{\mathrm{a}}$ and ${ }^{\mathrm{b}}$ denote significance at the $5 \%$, and $1 \%$ level. $\mathrm{B}$ is the estimate

negative impacts. While farmers reported that they did not receive regular support from national and international organizations, the results showed that such support positively influenced the adaptation to climate change. The agro-ecological zone of Korhogo was more likely to positively influence the re-sowing technique and the use of more seeds, while Toumodi was suitable to water retention through large holes for seedbeds. Indeed, cereal production is more suitable to the north than the center, which could explain farmers' propensity to adopt techniques to deal with the poor germination of seeds. Furthermore, the less the farmers grew roots, tubers, and cereals, the more likely they were to adapt by using the re-sowing technique and more seeds. However, making large holes for seedbeds positively influenced farmers' decision to adapt when producing roots and tubers. This technique is implemented for some crops such as cocoa, which was associated with yams. The ownership of animals positively influenced adaptation through the management of sowing. The results also showed that farmers' age, experience in crop farming, and household size included in component C 6 were not significant in the decision to adapt. This finding is opposite to what Gbetibouo et al. (2010) found, as experimental farmers are highly skilled in farming techniques and management and are able to spread risk when facing climate variability by exploiting strategic complementarities between activities. Finally, being a member of a farming association positively influenced adaptation, while access to climate information from television did not positively influence adaptation. Indeed, according to farmers, the information they obtained from television did not include any advice regarding adaptation methods, but rather provided only general information related to the temperature and rainfall for the next day. 
The results of the estimates for the logistic models to explain farmers' adaptation behavior through the management of their technical itinerary are presented in Table 9. The components "the perceived occurrence of new pests and weeds" and "agro-ecological zone, food crops, and livestock" were significant to all adaptation strategies through the technical itinerary management. Moreover, four other variables influenced several specific adaptation strategies in different ways. Indeed, the adoption of the crop association technique was positively influenced by the perception of the frequency and length of dry spells, while changes in the hillocks size were guided by the perception of changes in rainfall and rainy seasons. Piya et al. (2013) found the ability of households to perceive rainfall changes to be an important determinant of adaptation. Furthermore, the positive correlation between the perception of a significant increase in insect pests and weeds and overall adaptation strategies indicates that this was a relevant influencing factor of farmers' adaptation decision. In general, the agro-ecological zone of Korhogo seemed to be an environment where households have the higher propensity to change their technical itinerary, except for the strategy of keeping more trees in the fields, which was favorable in the Toumodi area. Indeed, the specific location as an important determinant of adaptation choices has also been reported by Piya et al. (2013) and Deressa et al. (2009). The strategy of changing the technical itinerary was encountered in root and tuber production. Farmers are believed to have learned this technique from television. Furthermore, the farmers who owned animals and grew cereals were more motivated to change their technical itinerary. Bryan et al. (2013) found similar results demonstrating that farmers engaged in both crop and livestock production were likely to change their crop variety. Regarding the component "household head characteristics," the adoption of short-season vegetable varieties was significantly influenced by an increase in experience, age, and household size; however, the crop association technique was adopted more frequently by young farmers. The influence of household size on the use of adaptation methods can be seen from two angles. First, households with large families may be forced to divert part of the labor force to off-farm activities in an attempt to earn income to ease the consumption pressure imposed by a large family. Second, a large family size is normally associated with a higher labor endowment, which would enable a household to accomplish various agricultural tasks (Yirga 2007; Deressa et al. 2009).

\section{Conclusion and policy implications}

The objectives of this study were to identify and analyze the factors that influence farmers' adaptation behavior regarding climate change. The results have shown that farmers have strong perceptions of changes in climatic conditions and their local environment. We found significant differences between farmers in the study areas with respect to their perceptions of changes in climatic conditions, except for their perceived changes in rainfall. Farmers in Toumodi perceived more changes in climate characteristics than those in Korhogo. Furthermore, between 23-27\% of farmers in Toumodi (resp. 46-52\% in Korhogo) perceived both an average increase in the frequency of dry spells and an average decrease in rainfall frequency.

Regarding the perception of the impacts of climate change, farmers from Korhogo perceived more new pests and weeds than farmers from Toumodi who, however, strongly agreed that there were changes in flowering and fruiting times. The study also identified eight major adaptation strategies, which were divided into sowing and technical itinerary management. The levels of implemented strategies differed significantly across regions, except for the adoption of short-season crops. 


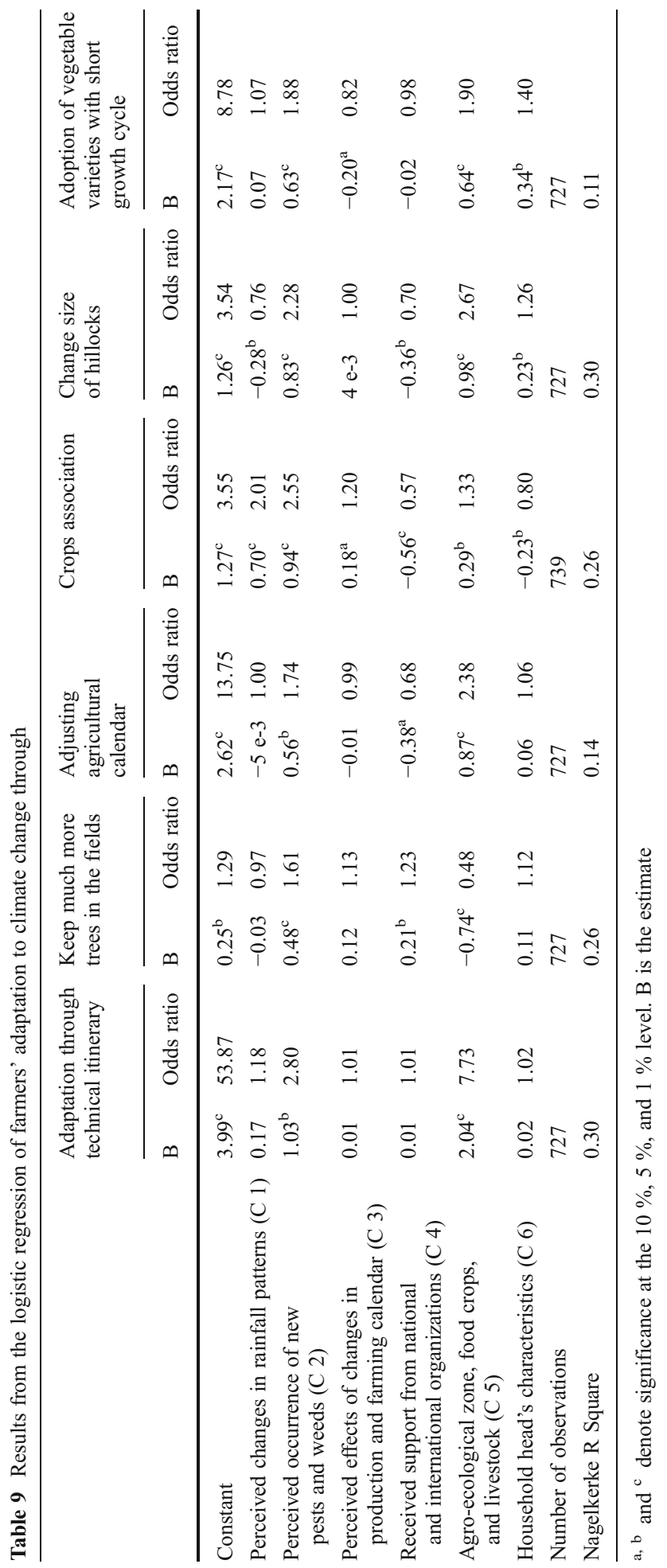


The decision to adapt occurred when farmers linked climate change to its negative impacts. For instance, the perceived occurrence of new pests and weeds motivated the adoption of re-sowing and making large holes for seedbeds, while it negatively influenced the use of more seeds. Moreover, it was only when farmers perceived a decrease in the length of rainy seasons and frequency of rainfall that they decided to make large holes for seedbeds. Surprisingly, age, household size, and experience in crop farming were not significantly related to the decision to adapt through sowing management. Concerning adaptation by changing the technical itinerary, the "perceived occurrence of new pests and weeds" and "agro-ecological zone, food crops, and livestock" were significant to all strategies. The adoption of the crop association technique was positively influenced by perceptions of the frequency and length of dry spells, while changes of hillock size were influenced by perceived changes in rainfall and rainy seasons. The potential wealth through owning animals and cereal was a positive factor related to adaptation. Moreover, the agroecological zone of Korhogo motivated farmers' adaptation, except for the technique of keeping significantly more trees in the fields, which was favorable in the Toumodi area. Increases in experience, age, and household size significantly influenced the adoption of new varieties with a short growing cycle, while the crop association technique was more frequently adopted by young farmers. A different direction of influence of these household characteristics was found in the literature; for instance, Shiferaw and Holden (1998) found a negative relationship between age and the adoption of improved soil conservation practices, whereas Deressa et al. (2009) showed that older farmers were more likely to employ adaptation strategies in the face of changes in climate-related variables. Although certain adaptation strategies were implemented in both study areas, the advice on adaptation strategies extended by national and international organizations has to take into account farmers' perceived impact of climate change, the agro-ecological zone, and farmers' characteristics. An additional way of extending information could be through television and other media, as the results revealed that these had a positive influence on adaptation behavior.

This study confirmed that adaptation might be conceptualized as a site-specific phenomenon to better target adaptation policies. Future policy has to aim at providing adaptation technologies through agro-ecology-based research (Deressa et al. 2009). Investing in agricultural extension at a national level and promoting NGOs and international organizations would be one of the best ways to improve farmers' adaptation, as our findings revealed the importance of support from these institutions in the adaptation process. Indeed, Bryan et al. (2013) found that autonomous adaptation is insufficient to address the threats posed by climate change. The rural poor need more support from the government, NGOs, and the private sector to enable them to move beyond short-term coping measures in response to climate shocks and to invest in long-term change. In Côte d'Ivoire, furthermore, adaptation that includes taking action to reduce risk as well as taking advantage of opportunities should be based on local NGOs in the north and the performance of ANADER and the Ministry of Agriculture in the Center, as Schmitt (2012) identified them as the most influential actors in these regions. Indeed, having access to extension increases the probability of choosing portfolio diversification by $4 \%$ (Gbetibouo et al. 2010). In addition, it is imperative to solve the lack of data on climate forecasts at the local level in Côte d'Ivoire by improving farmers' access to weather and climate-related information and their knowledge of the best adaptation strategies. Furthermore, in most developing countries such as Côte d'Ivoire, climate is infrequently integrated with development policy and investment decisionmaking. It needs to be revised to take into account farmers' perceptions of the climate change issue and their adaptation behavior at the local level. 


\section{References}

Adger N, Dessai S, Goulden M et al (2009) Are there social limits to adaptation to climate change? Clim Chang 93:335-354

Ahossane K, Jalloh A, Nelson GC et al (2013) Côte d'Ivoire, chapter 5. In West African Agriculture and Climate change: A Comprehensive Analysis. Research Monograph. International Food Policy Research Instittute (IFPRI), Washington, DC. doi:http://dx.doi.org/10.2499/9780896292048

Asfaw K, Jones J (2010) Climate change and human security in Africa. Int J Sustain Dev World Ecol 17(6):453-461

Birgit H, Bruzon V (2006) Profil Environnemental de la Côte d'Ivoire. Rapport Final. Consortium AGRIFOR Consult, p 133

Brou Y, Akindès F, Bigot S (2005) La variabilité climatique en Côte d'Ivoire: entre perceptions sociales et réponses agricoles. Cah Agric 14:533-540

Brou Y, Chaléard J (2007) Visions paysannes et changements environnementaux en Côte d'Ivoire. Annales de géographie 1:65-87

Bryan E, Deressa T, Gbetibuo G, Ringler C (2009) Adaptation to climate change in Ethiopia and South Africa: options and constraints. Environ Sci Pol 12(4):413-426

Bryan E, Ringler C, Okoba B et al (2013) Adapting agriculture to climate change in Kenya: Household strategies and determinants. J Environ Manag 114:26-35

Cissé G, Koné B, Hampaté Bâ et al. (2011) Ecohealth and Climate Change: Adaptation to flooding events in riverside secondary cities, West Africa. K. Otto-Zimmermann (ed), Resilient Cities: Cities and Adaptation to Climate 55. Change Proceedings of the Global Forum 2010, Local sustainability 1(2): 55-67

Comoé H, Finger R, Barjolle D (2012) Farm management decision and response to climate variability and change in Côte d'Ivoire. Mitig Adapt Strateg Glob Chang. doi:10.1007/s11027-012-9436-9

CountrySTAT Côte d'Ivoire (2012) Quantité des exportations des cultures et des produits de l'élevage. Retrieved June 4, 2012, from http://countrystat.org/civ/cont/inctables/pageid/8 mega/fr

Croppenstedt A, Demeke M, Meschi M (2003) Technology adoption in the presence of constraints: the case of fertilizer demand in Ethiopia. Rev Dev Econ 7(1):58-70

Deressa T, Hassan R, Ringler C, Alemu T, Yesuf M (2009) Determinants of farmers' choice of adaptation methods to climate change in the Nile Basin of Ethiopia. Glob Environ Chang 19:248-255

Di Falco S, Marcella V, Mahmud Y (2011) Does adaptation to climate change provide food security? A microperspective from Ethiopia. Am J Agric Econ 93(3):829-846

Dje K (2008) L'impact des changements climatiques sur le climat en Côte d'Ivoire. Contribution de la SODEXAM. Communication dans le cadre du rapport Mondial sur le Developpement Humain 2007/ 2008. UNEP

Esham M, Garforth C (2012) Agricultural adaptation to climate change: insights from a farming community in Sri Lanka. Mitig Adapt Strateg Glob Chang. doi:10.1007/s11027-012-9374-6

FAO (2000) Etude sur la vulgarisation agricole en Côte d'Ivoire. Retrieved from http://www.fao.org/sd/ FRdirect/EXre0028.htm

Field A (ed) (2009) Discovering statistics using SPSS. Sage publications, London

Gbetibouo G (2009) Understanding farmers' perceptions and adaptations to climate change and variability the case of the Limpopo Basin, South Africa. IFPRI Discussion paper 849

Gbetibouo G, Hassan R, Ringler C (2010) Modelling farmers' adaptation strategies for climate change and variability: the case of the Limpopo Basin, South Africa, Agrekon: Agricultural Economics Research. Pol Pract South Afr 49(2):217-234

Goroza G (2012) Impacts des changements climatiques dans les différentes zones agroclimatiques de l'Afrique de l'ouest en zone sub-humide. Cas de la Côte d'Ivoire. Météorologie Nationale de Côte d'Ivoire

Goula B, Srohourou B, Brida A et al (2010) Determination and variability of growing seasons in Côte d'Ivoire. Int J Eng Sci 2:5993-6003

Gschwend T (2005) Data, measures and methods. Analyzing quota sample data and the peer-review process. French Politics 3:88-91

Hansen J, Marx S, Weber E (2004) The role of climate perceptions, expectations, and forecasts in farmer decision making: the Argentine Pampas and South Florida. Final Report of an IRI Seed Grant Project. International Research Institute for Climate Prediction (IRI), the Earth Institute at Columbia University, USA

Hisali E, Birungi P, Buyinza F (2011) Adaptation to climate change in Uganda: evidence from micro level data. Glob Environ Chang 21:1245-1261

Igoden C, Ohoji P, Ekpare J (1990) Factors associated with the adoption of recommended practices for maize production in the Lake Basin of Nigeria. Agric Adm Ext 29(2):149-156 
IPCC (2001) In: Houghton JT, Ding Y, Griggs DJ, Noguer M, van der Linden PJ, Dai X, Maskell K, Johnson CA (eds) Climate change 2001: The scientific basis. Contribution of working group 1 to the third assessment report of the intergovernmental panel on climate change. Cambridge University Press, Cambridge

IPCC (2007) Climate change 2007: Synthesis report. Contribution of working groups I, II and III to the fourth assessment report of the intergovernmental panel on climate change. In: Pachauri RK, Reisinger A (eds) Core writing team. IPCC, Geneva

Izaurralde R (2009) Global climate change and agriculture. In: Pond WG, Nichols BL, Brown DL (eds) Adequate food for all: Culture, science, and technology of food in the 21 st century. CRC Press, Boca Raton

Kanohin F, Saley M, Savane I (2009) Impacts de la Variabilité Climatique Sur Les Ressources en Eau et Les Activites Humaines en Zone Tropicale Humide : Cas de la Région de Daoukro en Côte D' Ivoire. Eur J Sci Res 26(2):209-222

Krueger RA (ed) (1994) Focus groups: A practical guide for applied research. Thousand Oaks, CA: Sage Publications, London

Maddison D (2007) The perception of and adaptation to climate change in Africa. World bank policy research working paper 4308. The World Bank, Washington, DC

MEDD (Ministère de l'Environnement et du Développement Durable) (2011) Politique nationale de l'environnement. République de Côte d'Ivoire, p 90

Mertz O, Mbow C, Reenberg A, Diouf A (2009) Farmers' perceptions of climate change and agricultural adaptation strategies in rural Sahel. Environ Manag 43(5):804-816

MET (Ministère de l'Environnement et du Tourisme) (1994) Livre Blanc de l'Environnement de Côte d'Ivoire, Tome 1, p 179

Morgan DL (ed) (1997) Focus groups as qualitative research. In: Qualitative research methods series 16. Sage, London

Moser CA (1952) Quota sampling. Journal of the Royal Statistical Society. Series A (General) 115:411-423

MPARH (Ministère de la Production Animale et des Ressources Halieutiques) (2003) Rapport national sur l'état des ressources zoogénétiques. République de Côte d'Ivoire, p 80

Nhemachena C, Hassan R (2007) Micro-level analysis of farmers' adaptation to climate change in Southern Africa. IFPRI Discussion Paper No. 00714. International Food Policy Research Institute, Washington, DC

Nielsen J, Reenberg A (2010) Cultural barriers to climate change adaptation: a case study from Northern Burkina Faso. Glob Environ Chang 20:142-152

Ochou A (2011) Réchauffement Climatique : Origines, manifestations et impacts. communication. Ministère de l'Environnement et du Développement Durable. République de Côte d'Ivoire, p 59

Ouattara N (2001) Situation des ressources génétiques forestières de la Côte d'Ivoire (Zone de savanes). Note thématique sur les ressources génétiques forestières. FAO, p 49

PAM, FAO, MINAGRI, MIRAH (2012) Mission de suivi de la saison agricole et de la sécurité alimentaire 2011. Côte d'Ivoire

Piya L, Maharjan K, Joshi N (2013) Determinants of adaptation practices to climate change by Chepang households in the rural Mid-Hills of Nepal. Reg Environ Change 13:437-447

Schmitt E (2012) The importance of social networks to inform and support farmers about adaptation strategies regarding climate change in Côte d'Ivoire. Master thesis, Federal Institute of Technology (ETH) Zurich, Switzerland

Sebillotte M (1974) Agronomie et agriculture. Essai d'analyse des tâches de l'agronome. Cahier Orstom. Série Biologie 24:3-25

Shiferaw B, Holden S (1998) Resource degradation and adoption of land conservation technologies in the Ethiopian highlands: a case study in Andit Tid, North Shewa. Agric Econ 18:233-247

Sietz D, Boschütz M, Klein R (2011) Mainstreaming climate adaptation into development assistance: rationale institutional barriers and opportunities in Mozambique. Environ Sci Pol 14(4):493-502

Silvestri S, Bryan E, Ringler C, Herrero M, Okoba B (2012) Climate change perception and adaptation of agro-pastoral communities in Kenya. Reg Environ Chang. doi:10.1007/s10113-012-0293-6

Smit B, Wandel J (2006) Adaptation, adaptive capacity and vulnerability. Glob Environ Chang 16:282-292

Solano C, Bernués A, Rojas F, Joaquin N, Fernandez W, Herrero M (2000) Relationship between management intensity and structural and social variables: in dairy and dual purpose systems in Santa Cruz, Bolivia. Agric Syst 65:159-177

Tambo A, Tahirou A (2012) Climate change and agricultural technology adoption: the case of drought tolerant maize in rural Nigeria. Mitig Adapt Strateg Glob Chang 17:277-292

Thomas D, Twyman C, Osbahr H, Hewitson B (2007) Adaptation to climate change and variability: farmer responses to intra-seasonal precipitation trends in South Africa. Clim Chang 83(3):301-322 
Bi T, Diby L, Seyo E et al (2010) Estimating soil available nitrogen with a hot H2O2/KCl extraction. Scient Res and Essays 5:1455-1462

UFR-STRM (2009) Etude de faisabilité des forages manuels. Identification des zones potentiellement favorables. Etude réalisée avec la coordination de l'UFR-STRM. Laboratoire de Télédétection et de l'Analyse spatiale Appliquée à l'Hydrogéologie, validée à Lomé le 1 octobre 2009 par DGEA, République de Côte d'Ivoire, p 73

Yirga C (2007) The dynamics of soil degradation and incentives for optimal management in Central Highlands of Ethiopia. PhD Thesis, University of Pretoria, South Africa 